\title{
THE USE OF ACOUSTIC TELEMETRY TO MONITOR FISH SPECIES IN MARINE PROTECTED AREAS: A SYSTEMATIC REVIEW WITH NOTES ON BRAZILIAN PERSPECTIVES
}

\author{
Uso da telemetria acústica no monitoramento de peixes em \\ áreas marinhas protegidas: uma revisão sistemática com \\ notas sobre as perspectivas brasileiras
}

\author{
Daniel Lino Lippi*, Walter Dennis Menezes de Oliveira, \\ Camila Brasil Louro da Silveira, Beatrice Padovani Ferreira \\ Laboratório de Nécton - Grupo Lecor (Laboratório de Estudos em Ecossistemas Oceânicos e Recifais), \\ Departamento de Oceanografia da Universidade Federal de Pernambuco. \\ E-mail: daniel_lippi@hotmail.com*
}

\begin{abstract}
Inferring pathways used by organisms within ecosystems is essential to the design, management and evaluation of Marine Protected Areas (MPAs). This study aimed to present a systematic review on the literature regarding the use of acoustic telemetry to monitor marine fish movement and its application on MPAs. Searches were conducted on electronic databases. The first studies using telemetry on marine fish date back to the 60's, while application on MPAs only appeared 30 years later. However, over the last decade, studies in MPAs accounted for $20 \%$ of the overall acoustic telemetry publications on marine fish species. Recent technological development has had an important impact on those results. The number of studies inside MPAs followed the number of general studies and coverage areas of MPAs declared around the world, although frequency of studies did not match MPA coverage in some countries. Developed countries scored more studies, probably due to the relative high cost of acoustic telemetry. Studies in Brazilian MPAs are scarce, with only one study available on elasmobranchs. Brazil has recently increased its MPA coverage to $26 \%$, so it is expected to increase the need for MPA effectiveness studies. Brazilian participation on global tracking networks may help filling this gap.
\end{abstract}

Keywords: PRISMA statement, fish movement, remote monitoring, MPA effectiveness, tracking networks.

Recebido em: 11/10/2020

Aprovado em: 12/11/2020

Publicado online em: 20/05/2021 


\section{RESUMO}

O estudo da movimentação animal nos ecossistemas é uma importante ferramenta para a criação, o manejo e a avaliação de Áreas Marinhas Protegidas (AMPs). Este trabalho objetivou apresentar uma revisão bibliográfica sistemática na literatura científica abordando o uso de telemetria acústica para monitorar a movimentação de peixes e sua aplicação em AMPs. Para isso, foram realizadas pesquisas em bases de dados eletrônicas. Os primeiros estudos usando telemetria acústica em peixes datam da década de 1960, porém essa técnica só foi aplicada em AMPs 30 anos depois. Na última década, estudos em AMPs representaram 20\% do total de publicações com telemetria acústica com peixes em ambientes marinhos. $O$ desenvolvimento tecnológico recente teve um importante impacto nesses resultados. $O$ aumento no número de estudos realizados em AMPs foi congruente com o crescente número de estudos gerais de telemetria e com o aumento em áreas declaradas como AMPs globalmente. No entanto, não foi observada relação entre a frequência de estudos e a cobertura de AMP em alguns países. Países desenvolvidos produziram mais estudos, provavelmente devido ao alto custo da telemetria acústica. Estudos no Brasil foram escassos, com apenas um em elasmobrânquios. Recentemente, o Brasil elevou sua cobertura marinha protegida para $26 \%$, portanto, espera-se que isso impulsione estudos avaliando a efetividade de AMPs e que a participação brasileira em redes globais de telemetria ajude a preencher essa lacuna.

Palavras-chave: protocolo PRISMA, movimento de peixes, sensoriamento remoto, efetividade de AMPs, redes de telemetria.

\section{INTRODUCTION}

Movement is a key factor that shapes several aspects of fish behavior such as habitat use, home range size, reproduction and diel and seasonal activity patterns (e.g. Marshell et al., 2011; Lee et al., 2015; Di Lorenzo; Claudet \& Guidetti, 2016; Gandra; Erzini \& Abecasis, 2018) and therefore, influences the dynamics, structure and distribution patterns of fish populations. Telemetry, i.e. the remote measurement of biological variables, is a technology that allows gathering information on the biology and behaviour of the animals, including movement tracking, one of the most important preconditions for management decisions (Spedicato; Carbonara \& Lembo, 2005). It involves placing electronic devices ("transmitters" or "tags") on animals that auto-nomously transmit data to data logging or relay-receiving stations (Hussey et al., 2015).

One important driver behind growth in marine animal tracking studies has been the need for distribution and movement data to inform conservation policy and management (Hays et al., 2019). Marine Protected Areas (MPAs) are spatially delimited areas of the marine environment that are established for general conservation reasons, but expectations often include increased fishery catches in adjacent areas (Edgar; Russ \& Babcock, 2007). In 2010, the Convention on Biological Diversity (CBD), adopted the Strategic Plan for Biodiversity 2011-2020, which includes Aichi Biodiversity Targets. Aichi Target 11 called for $10 \%$ of coastal and marine areas to be conserved by 2020 through effectively managed, ecologically representative and well-connected systems of protected areas, and integrated into the wider landscapes and seascapes (SCBD, 2010). Thus, one important field of study to assess those attributes is the remote monitoring of marine organisms, including fish.

The present study aimed to present a systematic review on the scientific literature concerning the use of acoustic telemetry to monitor fish movement and its application on 
the design and assessment of MPAs, discussing the global expansion and recent advancements of the method. Brazil has just reached the mark of $20 \%$ of its Exclusive Economic Zone (EEZ) under a designated MPA (Soares \& Lucas, 2018), therefore the use of acoustic telemetry as a tool in Brazilian MPAs is also discussed as well as the role of global and regional collaborative tracking networks.

\section{MATERIALS AND METHODS}

In October 2020, two searches were conducted on electronic databases (Web of Science and SCOPUS) to identify the up-to-date relevant scientific literature on the use of acoustic telemetry to monitor fish species in marine or estuarine environments (Search 1) and specifically in marine protected areas (Search 2). Searches were conducted on the fields Title, Abstract and Author's keywords, and only articles published in English language were selected. The terms used on both searches are presented in Table I.

Search 1 returned a total of 1,203 publications after removals of duplicates. The article's titles, abstracts and keywords were then screened, and 897 studies remained for analysis. For the Search 2, the systematic review followed the steps defined in the Preferred Reporting Items for Systematic Reviews and Meta-Analyses (PRISMA) (Moher et al., 2009) (Figure 1). Articles were filtered for the quantitative analysis based on the following exclusion criteria: the study (I) addressed species other than fish (e.g. cuttlefish), (II) were not conducted in already implemented or designated (with well-established borders) marine protected areas and (III) evaluated MPA effectiveness based on simulation models. For each eligible article $(\mathrm{N}=157)$ the following data were compiled: year of publication, study location (country or territory), main objective, habitat type, species, number of tagged fish, overall duration of the study, application of other field methods (e.g. satellite tracking, mark-recapture) and partnership with tracking networks. Additionally, information on the size of implemented or designated MPAs for the countries listed in the articles were obtained from the Marine Protection Atlas website (MPAtlas.org, 2020).

Table I - Combination of terms used on the two searches performed on the Web of Science and Scopus databases. Searches were conducted on Title, Abstract and Author's keywords fields

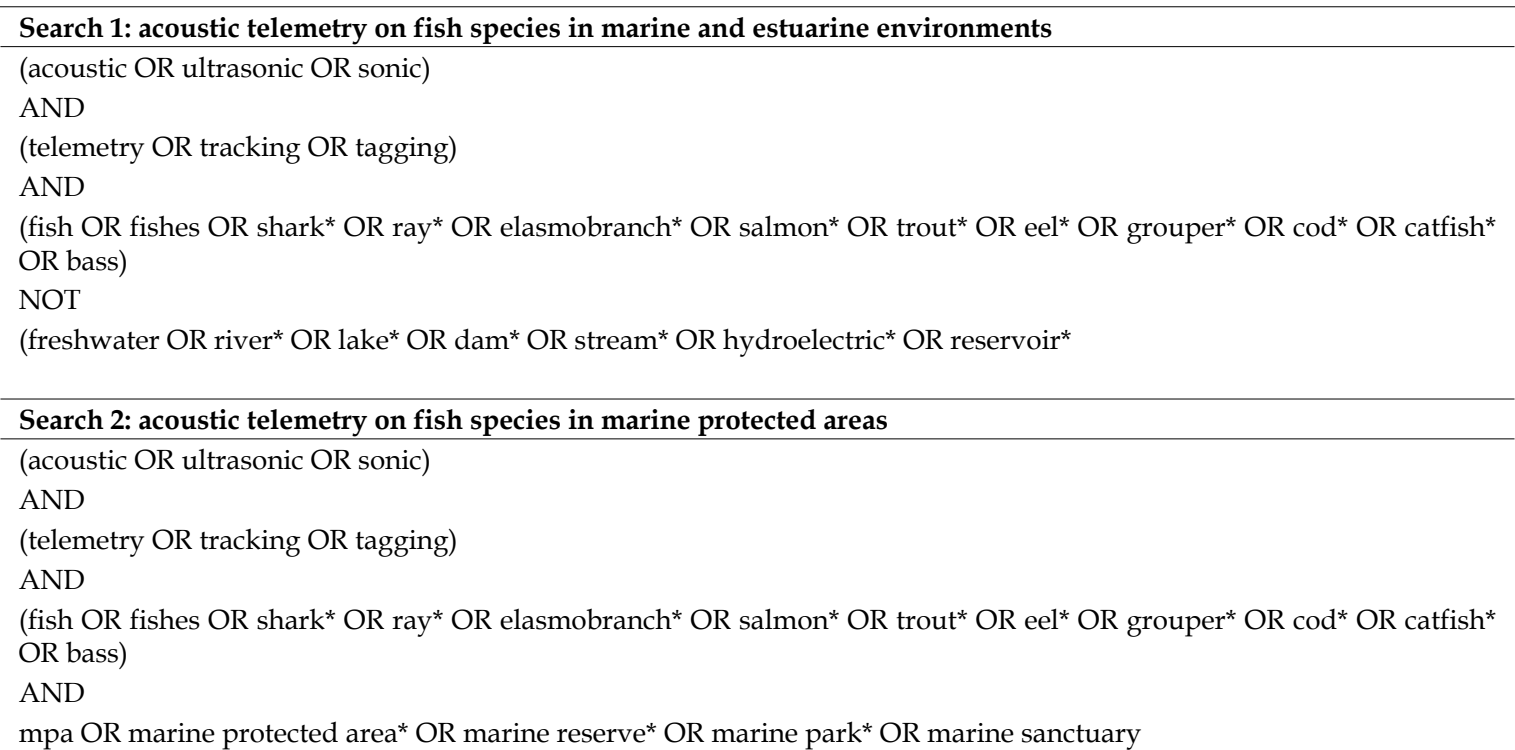


Figure 1 - PRISMA flow diagram for systematic review, including sample sizes and exclusion criteria

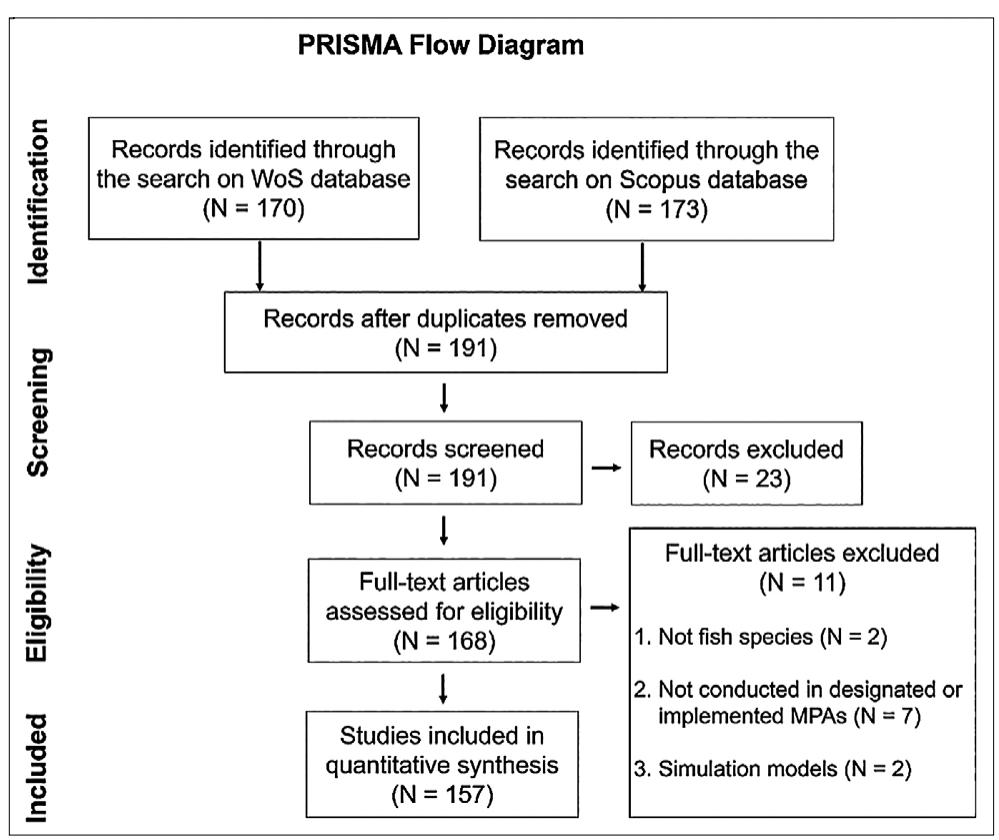

\section{RESULTS}

Studies using acoustic telemetry on fish species in marine or estuarine environments (Search 1, n = 897) were first published in the 1960's. The number of studies remained relatively low for the following decades (1965-1989) (Figure 2) with an average of less than 2 publications per year. During the 1990's, the number of publications increased fourfold (8 publications/year) and has been growing exponentially over the last decades: 2000-2009 (18 publications/year) and 2010-2020 (55 publications/year).

Figure 2 - Increase in the number of acoustic telemetry studies conducted on fish species in marine and estuarine environments (Search 1, light blue) and specifically in marine protected areas (MPAs) (Search 2, dark blue) since 1965

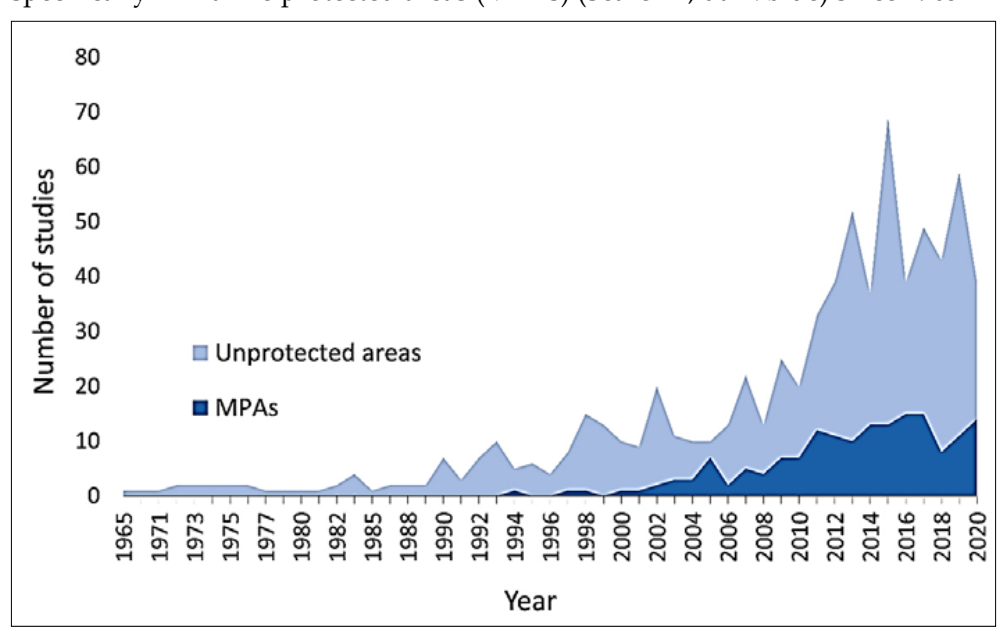

Studies reporting the use of acoustic telemetry to monitor fish species inside MPAs (Search 2, n = 157) were first published in the 1990's (Figure 2). Since then, the number of 
publications has increased from 3.4 per year (2000-2009) to 11 publications per year (20102020). All the results presented hereafter refer exclusively to the publications yielded by the second search, that is, the ones related to MPAs.

The found MPAs were located in 36 countries and territories. Three countries were responsible for $55 \%$ of the studies: United States of America (national waters and overseas territories; $28.5 \%, \mathrm{~N}=45)$, Australia $(19 \%, \mathrm{~N}=29)$ and Portugal $(7.5 \%, \mathrm{~N}=12)$, whereas two-thirds of the countries published only one or two studies (Figure 3). There was no correspondence between the percentage of MPAs (relative to the area of the EEZ of each country) and number of studies. While countries with low percentage of MPAs (e.g. Portugal, Italy and Spain) have a relatively high number of publications, other countries such as Brazil, Mexico and France have low numbers of studies despite the high percentage of their EEZ designated as MPAs.

Regarding the type of habitat covered by the MPAs, the majority of studies were conducted on coral or rocky reef habitats $(73.2 \%, \mathrm{~N}=115)$, followed by fewer studies $(10.2 \%)$ on unconsolidated substrate areas (e.g., seagrass or macroalgae beds, sand/mud bays and estuaries), mixed habitats (10.2\%) (i.e., mostly coral/rocky reefs associated to seagrass, sand or mangroves), open ocean, submerged banks or seamounts $(3.8 \%)$ and fjords or sounds $(2.6 \%)$. A total of 140 fish species (31 chondrichthyan and 109 teleost species) were acoustically monitored inside MPAs. The most studied families in terms of both number of studies and species were: Epinephelidae (28 studies and $17 \mathrm{spp}$.), Carcharhinidae (25 studies and 12 spp.), Sparidae (21 studies and 10 spp.), Lutjanidae (19 studies and 13 spp.) and Labridae (17 studies and 15 spp.). Many species (20\%) are under some level of threat, according to the criteria adopted by the international Union for conservation of Nature's Red List of Threatened Species - IUCN red list (Critically Endangered $=3$ spp., Endangered $=3$ spp. or Vulnerable $=22$ spp.), whereas some others are classified as Near Threatened (11.5\%, 16 spp.), Least concern (57.8\%, 81 spp.), Data Deficient (5.7\%, 8 spp.) and Not Evaluated (5\%, 7 spp.).

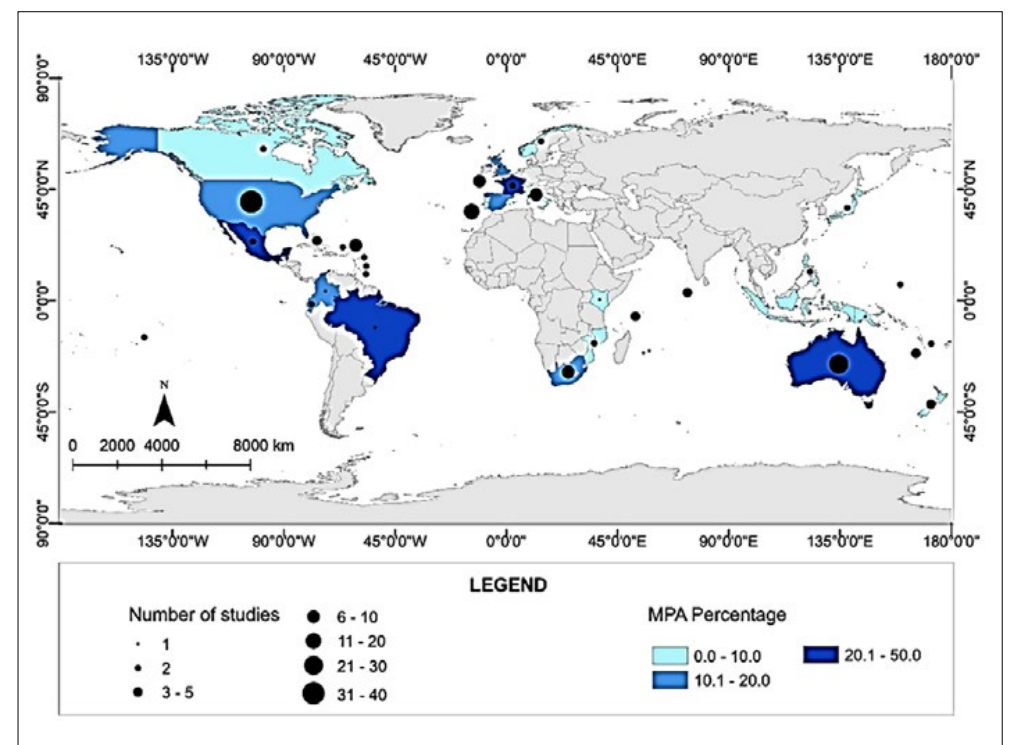

* Three territories (not distinguishable on the map) had more than $50 \%$ of theirs EEZ covered by MPAs: Martinique (99.7\%), Chagos Archipelago (98.02\%), and New Caledonia (94.25\%).
Figure 3 - Global map showing the locations (countries or territories) where the studies using acoustic telemetry on fish species were conducted in marine protected areas (MPAs). Shades of blue (light blue to dark blue) indicate the percentage of each country's Exclusive Economic Zone Covered by MPAs*. The number of studies is proportional to the black circle's size. Data source information: Coordinate System GCS WGS 1984; units: Degrees; datum: WGS 1984 
Acoustic telemetry has been mainly used as a tool to evaluate the protection effectiveness afforded by the MPAs to fish populations $(55.4 \%, \mathrm{~N}=87$ ) as well as to investigate spatial and temporal aspects of fish behavior $(38.2 \%, \mathrm{~N}=60)$. The majority of studies were performed in (or included) notake zones (112 out of 157). Fewer studies (3.8\%) focused on the assessment of specific human impacts (e.g. feeding activity and fishing mortality), on the development of analytical methods $(2 \%)$, and tag retention time $(0.6 \%)$. In most cases, studies were conducted on a single species at a time $(76.4 \%$, $\mathrm{N}=120$ ), with less studies tagging simultaneously two $(10.2 \%)$, three $(3.8 \%)$ or four or more species $(9.6 \%)$. Although less numerous, the number of studies with a multi-specific approach has increased over the past decade (Figure 4-A). A recent increase in the number of tagged individuals per study (Figure 4-B) and in the overall duration of the studies (Figure 4-C) was also observed.

Among the studies analyzed, 18 (11.5\%) were part of a regional or global tracking network: the Integrated Marine Observatory System (IMOS) in Australia ( $\mathrm{n}=13)$, the Acoustic Tracking Array Platform (ATAP) in South Africa $(\mathrm{n}=2)$, the Ocean Tracking Network FACT node (Florida Atlantic Coast Telemetry Network) $(\mathrm{n}=2)$ and the US Caribbean Acoustic Network USCAN ( $n=1)$.
Figure 4 - Number of published acoustic telemetry studies per year in relation to the: (A) number of tagged species, (B) number of tagged individuals and (C) duration of the studies

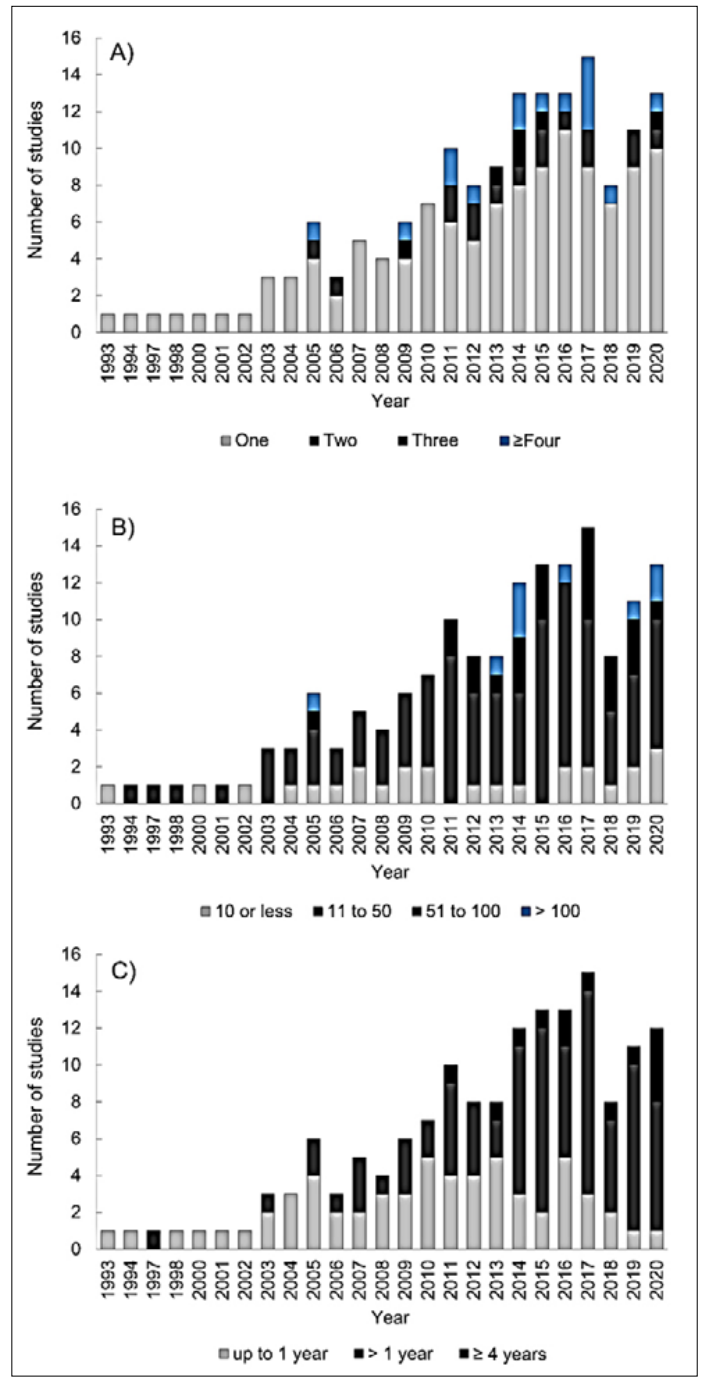

\section{DISCUSSION}

The onset of studies in acoustic telemetry on fish species in marine or estuarine environments was in the 1960's (Bass \& Rascovich, 1965). In subsequent decades, the number of studies remained low, experiencing an accelerated growth in the two last decades. Indeed, in recent decades, technological developments in miniaturization (March et al., 2011), battery engineering and hard and software development have enabled this development and the monitoring of aquatic organisms in a multitude of environments (Hussey et al., 2015).

However, studies using acoustic telemetry inside marine protected areas (MPAs) only started three decades later, in the 1990's (Holland et al., 1993), following the increase in the coverage area by MPAs declared worldwide (Worm, 2017; O'Leary et al., 2018). 
During the last decade, studies in MPAs accounted for $20 \%$ of the total number of published studies using fish acoustic telemetry in marine or estuarine environments.

The geographic distribution of those studies, however, was uneven. Although studies in MPAs were distributed across several countries and territories, three developed countries (United States of America, Australia, and Portugal) concentrated 55\% of the studies. The high number of studies in MPAs did not match the relative total area of MPAs of those countries either, as the three added covered only $28.4 \%$ of MPA area in the world: US (13.9\%), Australia (14.2\%) and Portugal (0.3\%) (MPAtlas.org, 2020). Indeed, countries with lower MPA areas (e.g. Portugal, Italy and Spain) had a higher number of studies in their MPAs in comparison with developing countries such as Brazil and Mexico, that showed a low number of studies despite the high percentage of their EEZ designated as MPAs. This difference is possibly related to the relative high cost of those studies, that even with technological improvements, remain expensive and limited to few manufactures located in developed countries (Garcia et al., 2014; Hellström et al., 2016).

It was observed that the main objective of the studies conducted on MPAs was to evaluate the protection effectiveness afforded to fish populations and most of them were performed in (or included) no-take zones. A high percentage of studies were concentrated on coral or rocky reef habitats, probably as those habitats typically harbor more territorial species (Sale, 2002; Burger \& Gochfeld, 2001), thus allowing for most cost-effective designs, and have shown positive effects deriving from MPA establishment (Steneck et al., 2018). Accordingly, the majority of studied families of bony fish in terms of both number of studies and species, were reef associated (e.g. groupers, snappers, and parrotfishes) (La Mesa et al., 2012; Garcia et al., 2014; Kendall et al., 2017). In addition, 20\% of the species were under some level of threat according to IUCN Red List criteria, indicating that those status make studies even more necessary (Afonso; Fontes \& Santos, 2011; Daly et al., 2020).

Another interesting finding was the increase, in the last decade, of the number of studies with a multi-specific approach. This application is especially important for studies dealing with the design and spatial effectiveness of MPAs. Data from acoustic telemetry show the overlap in the spatial occupation of prey and predator species, aggregations and movement of threatened species, essential information for marine spatial planning (Hussey et al., 2015). Another finding was the increase in the duration of the tracking period, also derived from technology improvement, and allowing for studies to encompass a significant period of life of individuals (Pittman et al., 2014).

In the last decade there was also an increase in the establishment of acoustic tracking networks, with the first study on MPAs, as part of a network, published in 2011 (Field et al. 2011). Since then, 18 studies were published as a result of regional or international partnerships. Two countries that concentrated the higher number of studies, US and Australia, also concentrated the networks cited. In Brazil, in spite of the still low number of published studies to date, a tracking network was created as part of the Ocean Tracking Network OTN, a Canadian based initiative that aims to form a global partnership that documents the movement and survival of aquatic animals to both understand how these populations are being influenced by changing environmental conditions and to support their sustainable management (Iverson et al., 2019).

Indeed, Brazil in spite of the higher percentage of MPAs (26\% of EEZ, although only $3.3 \%$ are considered fully or highly protected) (Soares \& Lucas, 2018) had only one study applying fish acoustic telemetry inside a MPA identified in the Search 2, out of the five 
studies detected for Brazil in Search 1. The study assessed the activity patterns of sharks inside the Marine Park of Fernando de Noronha (Garla; Gadig \& Garrone-Neto, 2017). In addition, another study on rays on the Saint Peter and Saint Paul Archipelago was identified (Mendonça et al., 2018). However, at the time of the study, the area had not yet been declared a protected area, and no mention was made to MPA in the study, so it was not added to the survey. It is worth mentioning that since 2018 the region has become a MPA (Soares \& Lucas, 2018). Also, two other acoustic telemetry studies conducted on elasmobranchs species inside Brazilian MPAs (Garla et al., 2006; Wetherbee; Gruber \& Rosa, 2007) were not identified on both searches as the surveyed terms (i.e., acoustic* OR sonic $^{*}$ OR ultrasonic*) were not mentioned on the articles' researched fields (title, abstract and author's keywords).

In Brazil, effectiveness of MPAs in terms of increase in the abundance and biomass of fish inside its boundaries has been relatively well documented (Floeter; Halpern \& Ferreira, 2006; Prates et al., 2007; Anderson et al., 2014), but reports on benefits through spillover to adjacent areas and effectiveness in terms of biodiversity protection and fisheries benefits are scarce. Also, connectivity of Brazilian MPAs through larval dispersion has been discussed (Endo et al., 2019), as well as its implication on the design of a representative MPA system (Magris et al., 2020).

The present study has shown that acoustic telemetry, as an effective technique to study fish movement, has been applied in the assessment of MPAs worldwide. In spite of comparatively high costs in relation to other techniques (e.g. UVC, mark-recapture and larval dispersal modelling) the results are unique and can also show direct benefits for adjacent areas (Reyier et al., 2020). Moreover, considering the impacts in marine habitats caused by human actions, including climate change, acoustic telemetry arises as an important tool in inferring and predicting how organisms and communities rearrange themselves when faced with environmental changes (Hussey et al., 2015).

Brazil still has a low number of studies in marine acoustic telemetry in general, with most of them addressing elasmobranchs species (Ferreira et al., 2013; Afonso \& Hazin, 2014; Mendonça et al., 2018) and only one study regarding bony fishes (Pinheiro et al., 2018). So, in order to boost such kind of studies, a partnership with an international acoustic tracking network was established in 2015 (Iverson et al., 2019; Pinheiro et al., 2018) aiming mutual benefits among partners, through national and international data interchange and collaboration. In that sense, it is expected that incentives for MPA effectiveness studies and Brazilian participation on networks may help to fill this gap.

Acknowledgements - The authors thank the Conselho Nacional de Desenvolvimento Científico e Tecnológico (CNPq) for DLL PhD grant (140950/2016-8) and BPF Productivity Research grant (309216/2018-4). We also thank the Coordenação de Aperfeiçoamento de Pessoal de Nível Superior - Brasil (Capes) for CBLS grant (88887.461761/2019-00) and the Fundação de Amparo à Ciência e Tecnologia do Estado de Pernambuco (Facepe) for WDMO PhD grant (PBGP-0539-1.08/20). This research is a contribution of the Long-Term Ecological Research Program (PELD-CNPq 441632/2016-5 ILTER-Brazil-Tamandaré site 18). 


\section{REFERENCES}

Afonso, A.S. \& Hazin, F.H.V. Post-release survival and behavior and exposure to fisheries in juvenile tiger sharks, Galeocerdo cuvier, from the South Atlantic. Journal of Experimental Marine Biology and Ecology, v. 454, p. 55-62, 2014. Available at: http://www.sciencedirect. com/science/article/pii/S0022098114000410. Accessed: 10 Nov. 2020.

Afonso, P.; Fontes, J. \& Santos, R.S. Small marine reserves can offer long term protection to an endangered fish. Biological Conservation, v. 144, n. 11, p. 2739-2744, 2011. Available at: http:// www.sciencedirect.com/science/article/pii/S0006320711002916. Accessed: 9 Dez. 2020.

Anderson, A.; Bonaldo, R.; Barneche, D.; Hackradt, C.; Félix-Hackradt, F.; García-Charton, J. \& Floeter, S. Recovery of grouper assemblages indicates effectiveness of a marine protected area in Southern Brazil. Marine Ecology Progress Series, v. 514, p. 207-215, 2014. Available at: http://www.int-res.com/abstracts/meps/v514/p207-215/. Accessed: 10 Nov. 2020.

Bass, G.A. \& Rascovich, M. A device for the sonic tracking of large fishes. Zoologica: scientific contributions of the New York Zoological Society, v. 50, n. 8, p. 75-82, 1965. Available at: https:/ / www.biodiversitylibrary.org/part/203272. Accessed: 10 Nov. 2020.

Burger, J. \& Gochfeld, M. On developing bioindicators for human and ecological health. Environmental Monitoring and Assessment, v. 66, n. 1, p. 23-46, 2001. Available at: https:// doi.org/10.1023/ A:1026476030728. Accessed: 10 Nov. 2020.

Daly, R.; Daly, C.A.K.; Gray, A.E.; Peel, L.R.; Gordon, L.; Lea, J.S.E.; Clarke, C.R. \& Weng, K.C. Investigating the efficacy of a proposed marine protected area for the endangered humphead wrasse Cheilinus undulatus at a remote island group in Seychelles. Endangered Species Research, v. 42, p. 7-20, 2020. Available at: https:/ /www.int-res.com/abstracts/esr/ v42/p7-20/. Accessed: 9 Dez. 2020.

Di Lorenzo, M.; Claudet, J. \& Guidetti, P. Spillover from marine protected areas to adjacent fisheries has an ecological and a fishery component. Journal for Nature Conservation, v. 32, p. 62-66, 2016. Available at: https://linkinghub.elsevier.com/retrieve/pii/S16171381163 00255. Accessed: 10 Nov. 2020.

Edgar G.J.; Russ, G.R. \& Babcock, R.C. Marine protected areas, p. 534-565, in Connell, S.D. \& Gillanders, B.M. (ed.), Marine Ecology. Oxford University Press. ISBN: 0195553020. 2007.

Endo, C.A.K.; Gherardi, D.F.M.; Pezzi, L.P. \& Lima, L.N. Low connectivity compromises the conservation of reef fishes by marine protected areas in the tropical South Atlantic. Scientific Reports, v. 9, n. 1, p. 8634, 2019. Available at: http://www.nature.com/articles/ s41598-019-45042-0. Accessed: 10 Nov. 2020.

Ferreira, L.C.; Afonso, A.S.; Castilho, P.C. \& Hazin, F.H.V. Habitat use of the nurse shark, Ginglymostoma cirratum, off Recife, Northeast Brazil: a combined survey with longline and acoustic telemetry. Environmental Biology of Fishes, v. 96, n. 6, p. 735-745, 2013. Available at: https://doi.org/10.1007/s10641-012-0067-5. Accessed: 10 Nov. 2020.

Field, I.C.; Meekan, M.G.; Speed, C.W.; White, W. \& Bradshaw, C.J.A. Quantifying movement patterns for shark conservation at remote coral atolls in the Indian Ocean. Coral Reefs, p. 11, 2011. Available at: https://doi.org/10.1007/s00338-010-0699-x. Accessed: 10 Nov. 2020. 
Floeter, S.R.; Halpern, B.S. \& Ferreira, C.E.L. Effects of fishing and protection on Brazilian reef fishes. Biological Conservation, v. 128, n. 3, p. 391-402, 2006. Available at: https:// linkinghub.elsevier.com/retrieve/pii/S0006320705004167. Accessed: 10 Nov. 2020.

Gandra, M.; Erzini, K. \& Abecasis, D. Diel and seasonal changes in the spatial behaviour of a soft-sediment fish (Solea senegalensis) inside a marine reserve. Marine Environmental Research, v. 135, p. 82-92, 2018. Available at: http://www.sciencedirect.com/science/ article/pii/S0141113617306220. Accessed: 10 Nov. 2020.

Garcia, J.; Rousseau, Y.; Legrand, H., Saragoni, G. \& Lenfant, P. Movement patterns of fish in a Martinique MPA: implications for marine reserve design. Marine Ecology Progress Series, v. 513, p. 171-185, 2014. Available at: https://www.int-res.com/abstracts/meps/ v513/p171-185/. Accessed: 9 Dez. 2020.

Garla, R.C.; Chapman, D.D.; Wetherbee, B.M. \& Shivji, M. Movement patterns of young Caribbean reef sharks, Carcharhinus perezi, at Fernando de Noronha Archipelago, Brazil: the potential of marine protected areas for conservation of a nursery ground. Marine Biology, v. 149, n. 2, p. 189-199, 2006. Available at: https://doi.org/10.1007/s00227-0050201-4. Accessed: 9 Dez. 2020.

Garla, R.C.; Gadig, O.B.F. \& Garrone-Neto, D. Movement and activity patterns of the nurse shark, Ginglymostoma cirratum, in an oceanic Marine Protected Area of the South-western Atlantic. Journal of the Marine Biological Association of the United Kingdom, v. 97, n. 8, p. 15651572, 2017. Available at: https://www.cambridge.org/core/product/identifier/S00 25315416001028/type/journal_article. Accessed: 10 Nov. 2020.

Hays, G.C.; Bailey, H.; Bograd, S.J.; Bowen, W.D.; Campagna, C.; Carmichael, R.H.; Casale, P.; Chiaradia, A.; Costa, D.P.; Cuevas, E.; Nico de Bruyn, P.J.; Dias, M.P.; Duarte, C.M.; Dunn, D.C.; Dutton, P.H.; Esteban, N.; Friedlaender, A.; Goetz, K.T.; Godley, B.J. \& Sequeira, A.M.M. Translating marine animal tracking data into conservation policy and management. Trends in Ecology \& Evolution, v. 34, n. 5, p. 459-473, 2019. Available at: http://www. sciencedirect.com/science/article/pii/S0169534719300242. Accessed: 10 Nov. 2020.

Hellström, G.; Klaminder, J.; Jonsson, M.; Fick, J. \& Brodin, T. Upscaling behavioural studies to the field using acoustic telemetry. Aquatic Toxicology, v. 170, p. 384-389, 2016. Available at: http://www.sciencedirect.com/science/article/pii/S0166445X15300886. Accessed: 9 Dez. 2020.

Holland, K.N.; Peterson, J.D.; Lowe, C.G. \& Wetherbee, B.M. Movements, distribution and growth rates of the white goatfish Mulloides flavolineatus in a fisheries conservation zone. Bulletin of Marine Science, v. 52, n. 3, p. 982-992, 1993. Available at: https://www. ingentaconnect.com/content/umrsmas/bullmar/1993/00000052/00000003/art00011. Accessed: 10 Nov. 2020.

Hussey, N.E.; Kessel, S.T.; Aarestrup, K.; Cooke, S.J.; Cowley, P.D.; Fisk, A.T.; Harcourt, R.G.; Holland, K.N.; Iverson, S.J.; Kocik, J.F.; Mills Flemming, J.E. \& Whoriskey, F.G. Aquatic animal telemetry: a panoramic window into the underwater world. Science, v. 348, n. 6240, p. 1255642-1255642, 2015. Available at: https://www.sciencemag.org/lookup/ doi/10.1126/science.1255642. Accessed: 10 Nov. 2020.

Iverson, S.J.; Fisk, A.T.; Hinch, S.G.; Flemming, J.M.; Cooke, S.J. \& Whoriskey, F.G. The ocean tracking network: advancing frontiers in aquatic science and management. Canadian 
Journal of Fisheries and Aquatic Sciences, 2019. Available at: https://cdnsciencepub.com/ doi/abs/10.1139/cjfas-2018-0481. Accessed: 10 Nov. 2020.

Kendall, M.S.; Siceloff, L.; Winship, A. \& Monaco, M.E. Determining conservation potential of an opportunistically defined MPA boundary using fish telemetry. Biological Conservation, v. 211, p. 37-46, 2017. Available at: http://www.sciencedirect.com/science/article/pii/ S0006320716310898. Accessed: 9 Dez. 2020.

La Mesa, G.; Consalvo, I.; Annunziatellis, A. \& Canese, S. Movement patterns of the parrotfish Sparisoma cretense in a Mediterranean marine protected area. Marine Environmental Research, v. 82, p. 59-68, 2012. Available at: http://www.sciencedirect.com/science/ article/pii/S0141113612001663. Accessed: 9 Dez. 2020.

Lee, K.A.; Huveneers, C.; Macdonald, T. \& Harcourt, R.G. Size isn't everything: movements, home range, and habitat preferences of eastern blue gropers (Achoerodus viridis) demonstrate the efficacy of a small marine reserve. Aquatic Conservation: Marine and Freshwater Ecosystems, v. 25, n. 2, p. 174-186, 2015. Available at:https://onlinelibrary.wiley.com/doi/abs/10.1002/ aqc.2431. Accessed: 10 Nov. 2020.

Magris, R.A.; Costa, M.D.P.; Ferreira, C.E.L.; Vilar, C.C.; Joyeux, J.; Creed, J.C.; Copertino, M.S.; Horta, P.A.; Sumida, P.Y.G.; Francini-Filho, R.B. \& Floeter, S.R. A blueprint for securing Brazil's marine biodiversity and supporting the achievement of global conservation goals. Diversity and Distributions, p. ddi.13183, 2020. Available at: https://onlinelibrary. wiley.com/doi/10.1111/ddi.13183. Accessed: 10 Nov. 2020.

March, D.; Alós, J.; Grau, A. \& Palmer, M. Short-term residence and movement patterns of the annular seabream Diplodus annularis in a temperate marine reserve. Estuarine, Coastal and Shelf Science, v. 92, n. 4, p. 581-587, 2011. Available at: https://linkinghub.elsevier. com/retrieve/pii/S0272771411000746. Accessed: 10 Nov. 2020.

Marshell, A.; Mills, J.S.; Rhodes, K.L. \& McIlwain, J. Passive acoustic telemetry reveals highly variable home range and movement patterns among unicornfish within a marine reserve. Coral Reefs, v. 30, n. 3, p. 631-642, 2011. Available at: http://link.springer. com/10.1007/s00338-011-0770-2. Accessed: 10 Nov. 2020.

Mendonça, S.A.; Macena, B.C.L.; Afonso, A.S. \& Hazin, F.H.V. Seasonal aggregation and diel activity by the sicklefin devil ray Mobula tarapacana off a small, equatorial outcrop of the Mid-Atlantic Ridge. Journal of Fish Biology, v. 93, n. 6, p. 1121-1129, 2018. Available at: https://onlinelibrary.wiley.com/doi/abs/10.1111/jfb.13829. Accessed: 10 Nov. 2020.

Moher, D.; Liberati, A.; Tetzlaff, J.; Altman, D.G. \& Group, T.P. Preferred reporting items for systematic reviews and meta-analyses: the PRISMA Statement. PLOS Medicine, v. 6, n. 7, p. e1000097, 2009. Available at: https://journals.plos.org/plosmedicine/article?id= 10.1371/journal.pmed.1000097. Accessed: 10 Nov. 2020.

MPAtlas.org. 2020. Available at: https:/ / www.mpatlas.org. Accessed on: 25 Oct. 2020.

O’Leary, B.C.; Ban, N.C.; Fernandez, M.; Friedlander, A.M.; García-Borboroglu, P.; Golbuu, Y.; Guidetti, P.; Harris, J.M.; Hawkins, J.P.; Langlois, T.; McCauley, D.J.; Pikitch, E.K.; Richmond, R.H. \& Roberts, C.M. Addressing criticisms of large-scale marine protected areas. BioScience, v. 68, n. 5, p. 359-370, 2018. Available at: https://academic.oup.com/ bioscience/article/68/5/359/4953612. Accessed: 10 Nov. 2020. 
Pinheiro, I.E.G.; Muelbert, M.M.C.; Pedrosa, V.F.; Romano, L.A. \& Muelbert, J.H. Evaluation of intracoelomic tagging of tainha, Mugil liza (Valenciennes, 1836), under laboratory conditions. Hydrobiologia, v. 813,n.1, p. 213-222,2018. Availableat:https://doi.org/10.1007/ s10750-018-3527-x. Accessed: 10 Nov. 2020.

Pittman, S.J.; Monaco, M.E.; Friedlander, A.M.; Legare, B.; Nemeth, R.S.; Kendall, M.S.; Poti, M.; Clark, R.D.; Wedding, L.M. \& Caldow, C. Fish with chips: tracking reef fish movements to evaluate size and connectivity of Caribbean marine protected areas. PLoS ONE, v. 9, n. 5, p. e96028, 2014. Available at: https://dx.plos.org/10.1371/journal. pone.0096028. Accessed: 10 Nov. 2020.

Prates, A.P.; Cordeiro, A.Z.; Ferreira, B.P. \& Maida, M. Unidades de conservação costeiras e marinhas de uso sustentável como instrumento para gestão pesqueira, p. 25-38, in MMA/ SBF (org.). Áreas Aquáticas Protegidas como Instrumento de Gestão Pesqueira. Brasília: Série Áreas Protegidas, 2007.

Sale, P.F. Coral reef fishes. [s.l.]: Elsevier, 549 p., 2002. Available at: https://linkinghub. elsevier.com/retrieve/ pii/B9780126151855X50002. Accessed: 10 Nov. 2020.

Reyier, E.A.; Scheidt, D.M.; Stolen, E.D.; Lowers, R.H.; Holloway-Adkins, K.G. \& Ahr B.J. Residency and dispersal of three sportfish species from a coastal marine reserve: Insights from a regional-scale acoustic telemetry network. Global Ecology and Conservation, v. 23, p. e01057, 2020. Available at: http://www.sciencedirect.com/science/article/pii/S2351 989419309400. Accessed: 9 Dez. 2020.

Secretariat of the Convention on Biological Diversity (SCBD). Aichi biodiversity targets. 2010. Available at: https://www.cbd.int/sp/targets. Accessed: $1^{\circ}$ Nov. 2020.

Soares, M.O. \& Lucas, C.C. Towards large and remote protected areas in the South Atlantic Ocean: St. Peter and St. Paul's Archipelago and the Vitória-Trindade Seamount Chain. Marine Policy, v. 93, p. 101-103, 2018. Available at: https://linkinghub.elsevier.com/ retrieve/pii/S0308597X18301350. Accessed: 10 Nov. 2020.

Spedicato, M. T.; Carbonara, P. \& Lembo, G. Insight into the homing behaviour of the dusky grouper (Epinephelus marginatus Lowe, 1834) around the island of Ustica, Italy. 2005. Available at: https://agris.fao.org/agris-search/search.do?recordID=AV20120124131. Accessed: 10 Nov. 2020.

Steneck, R.S.; Mumby, P.J.; MacDonald, C.; Rasher, D.B. \& Stoyle, G. Attenuating effects of ecosystem management on coral reefs. Science Advances, v. 4, n. 5, p. eaao5493, 2018. Available at: https://advances.sciencemag.org/lookup/doi/10.1126/sciadv.aao5493. Accessed: 10 Nov. 2020.

Wetherbee, B.M.; Gruber, S.H. \& Rosa, R.S. Movement patterns of juvenile lemon sharks Negaprion brevirostris within Atol das Rocas, Brazil: a nursery characterized by tidal extremes. Marine Ecology Progress Series, v. 343, p. 283-293, 2007. Available at: https:// www.int-res.com/abstracts/meps/v343/p283-293/. Accessed: 9 Dez. 2020.

Worm, B. How to heal an ocean. Nature, v. 543, n. 7647, p. 630-631, 2017. Available at: http://www.nature.com/articles/nature21895. Accessed: 10 Nov. 2020. 